\title{
ПРЕСА УКРАЇНСЬКОЇ ЕМІГРАЦІЇ ЯК ДЖЕРЕЛО ВИВЧЕННЯ КУЛЬТУРИ, ОСВІТИ ТА ПОВСЯКДЕННОГО ЖИТТЯ УКРАЇНЦІВ (1920-ТІ РОКИ)
}

\section{О. В. Вовк}

Сумський державний педагогічний університет імені А. С. Макаренка вул. Роменська, 87, Суми, 40002. Україна. E-mail: o.v.vovk@gmail.com

Проаналізовано українські періодичні видання в діаспорі (1920-ті роки) в якості джерела вивчення культури, освіти, повсякденного життя українців, котрі мешкали на окупованій більшовиками території та за кордонами України. На основі вивчення ряду періодичних видань української еміграції з'ясовано, що публікації широко висвітлюють життя українців як за межами рідної землі, так і в різних країнах світу. Вибірка видань, які були вивчені, грунтується на тому, що кожне з них представляло якесь громадську чи політичну спільноту, яка мала власний погляд на соціокультурні процеси та ставлення до них. 3'ясовано, що багато матеріалів української зарубіжної преси у міжвоєнний період було присвячено питанням розвитку української культури, освіти, зокрема, становище освітян та діяльність освітніх закладів. Розлого проілюстровано актуальні проблеми повсякдення українців, розділених кордонами між різними країнами.

Ключові слова: преса, культура, освіта, джерело, повсякденне життя.

\section{ПРЕССА УКРАИНСКОЙ ЭМИГРАЦИИ КАК ИСТОЧНИК ИЗУЧЕНИЯ КУЛЬТУРЫ, ОБРАЗОВАНИЯ И ПОВСЕДНЕВНОЙ ЖИЗНИ УКРАИНЦЕВ (1920-Е ГОДЫ)}

\section{А. В. Вовк}

Сумский государственный педагогический университет имени А. С. Макаренко

ул. Роменская, 87, Сумы, 40002. Украина. E-mail: o.v.vovk@gmail.com

Проанализировано украинские периодические издания в диаспоре (1920-е годы) как источник изучения культуры, образования, повседневной жизни украинцев, которые жили на оккупированной большевиками территории и за границами Украины. На основе изучения ряда периодических изданий украинской эмиграции выяснен вопрос о том, что публикации широко раскрывают жизнь украинцев, как за территорией родной земли, так и в разных странах мира. Выборка изданий, которые были изучены, основывается на том, что каждое из них представляло какое-то гражданское или политическое сообщество, которое имело собственный взгляд по поводу социокультурных вопросов и отношение к ним. Выяснено, что много материалов украинской зарубежной прессы в межвоенный период было посвящено вопросам развития украинской культуры, образования, а именно, положению работников образования, деятельности образовательных учреждений. Широко проиллюстрировано актуальные проблемы повседневной жизни украинцев, разделенных границами между разными странами.

Ключевые слова: пресса, культура, образование, источник, повседневная жизнь.

АКТУАЛЬНІСТЬ РОБОТИ. Історія української культури, освіти, повсякденного життя є актуальною темою сучасних наукових досліджень. Існує ряд джерел, що дають можливість вивчити вказані питання. Серед згаданих джерел, що ілюструють життя українців у міжвоєнний період, окремо можна виділити пресу. Попри те, що періодичні видання української діаспори мають певний «партійний» стиль, але, порівнюючи 3 газетами та журналами України, що перебувала під більшовицькою окупацією, діаспорна преса мала можливість значно об'єктивніше висвітлювати ряд питань, про які говорити чи писати в УСРР офіційно не можна було. Якщо говорити про те, на скільки правдивою була інформація про соціокультурні процеси у Наддніпрянщині, то про об'єктивність можна говорити, порівнюючи інформацію з інших джерел: архівних документів, спогадів очевидців. Чимала кількість наукових публікацій, присвячених цьому історичному періоду, засвідчуе, що в цілому матеріали зарубіжної преси здебільшого об'єктивно висвітлюють напрямки розвитку культури, освіти, повсякдення українців, що мешкали в УСРР. Слід пам'ятати, що тривалий час українська громадськість на еміграції здійснювала заходи для підготовки до майбутнього визволення України. Провадився глибокий аналіз суспільно-політичних та економічних процесів на основі різних джерел, в тому числі й агентурних, матеріалів у більшовицькій пресі. Якщо мова йде про культурний процес в середовищі українців, розпорошених серед різних країн, то в цьому випадку закордонна преса $є$ для нас досить цінним джерелом, оскільки матеріали у виданнях готували безпосередні учасники або свідки українського життя. Отже, вивчення української емігрантської преси як джерела соціокультурних процесів, може принести вагомі результати у справі вивчення історії української культури, освіти.

МАТЕРІАЛ І РЕЗУЛЬТАТИ ДОСЛІДЖЕНЬ. ВИвченню української преси як джерела для висвітлення історичного процесу присвячена значна кількість праць. Зазвичай, дослідники приділяли увагу якомусь історичному етапові і в цьому контексті розглядали проблему існування української преси. Одним з перших науковців, котрий вперше намагався системно дослідити українську пресу, був А. Животко. [1] У його праці здійснена важлива дослідницька робота, що спиралася на аналізі еміграційних джерел, широкій аналітичній роботі. Праця М. Мартинюка [2] подавала загальну картину розвитку українських періодичних видань в еміграції. Крім згаданих дослідників, слід також вказати на здобутки у галузі вивчення української преси таких авторів, як, І. ЛисякРудницький [3], Н. Сидоренко [4], О. Вішка [5], М. Савка [6], О. Денека [7], В. Трощинський [8]. Грунтовна праця О. Богуславського [9] стосується безпо- 
середньої проблеми нашого дослідження і присвячена пресі української еміграції в контексті боротьби за незалежність України. І. Крупський [10] вважав, що українські часописи в еміграції виконували важливу соціальну функцію, забезпечуючи публічну дискусію 3 проблем культурного, господарського, наукового життя.

Проблема української еміграційної преси знайшла своє висвітлення в історіографії. Висвітлювалася роль періодичної преси в контексті громадськокультурного, освітнього, жіночого руху української еміграції. Дослідниками розкривається значення та роль періодичних видань для окреслення завдань української військової еміграції, йдеться про завдання, що постали перед емігрантською молоддю. У сучасних дослідженнях знаходимо висвітлення зовнішньоінформаційної акції політичного емігрантського середовища УНР, проблем розв'язання та боротьби з ворожою пропагандою, ролі емігрантських часописів у розбудові спільного фронту демократичної періодики, участі у міжпартійній полеміці, 3'ясуванні проблем міжнаціональних відносин. Дослідники вивчали українські еміграційні періодичні видання і в контексті діяльності політичних діячів борців за українську державність, участі уряду УНР в еміграції у прометеївському русі (політичному, культурному, інтелектуальному русі).

Важливою рисою $є$ те, що більшість істориків розглядали емігрантські періодичні видання головним чином в контексті життя української еміграції. Як інформативне джерело про соціокультурні процесі в Україні під більшовицькою окупацією ці видання недооцінювалися. Хоча, як ми бачимо, в науці $\epsilon$ вагомий доробок в галузі вивчення української емігрантської преси, але певні аспекти та особливості ще не розкриті.

Емігрантська періодична преса періоду між двома світовими війнами представлена широкою кількістю видань. Проаналізувати їх усі в контексті дослідження розвитку української культури, освіти, повсякдення $\epsilon$ завданням, яке потребує тривалого вивчення. Нашою метою $є$ на основі окремих українських еміграційних видань, що виходили у 20-30-х роках XX століття, з'ясувати, як у них висвітлюється тема розвитку української культури.

Серед видань української еміграції міжвоєнного періоду можна назвати «Нову Громаду. Суспільнополітичний журнал», що виходив у 1923-1925 pp. у Відні під редакцією Семена Вітика. Попри критику часопису в емігрантських колах, що не розділяли політичних поглядів редактора, у цьому виданні можна знайти ряд публікацій, що стосуються актуальних соціокультурних проблем того часу. Наприклад, в одному 3 номерів автор публікації А. Дніпровський на підстав вивчення більшовицької преси, робить аналіз нових тенденцій у селянській поезії України. Мова йде про вихідця з села Івана Сенченка, що 3 хвилею розгортання революції 3 «мрійних м'яких степів та казкових гаїв» потрапляе під «кам'яний брук» міста, не може його сприйняти, обурюється ним, вбачає в ньому «ментального бронтозавра» зі «смородом проституції», хоче втікати 3 нього:
«Прощай, місто!

О як я тебе зневажаю;

Твій кам'яний брук,

Твої вітрини і димарі, що роздирають хмари.

Прощай!

Обернуся до тебе спиною

І піду по світу...

Я не хочу більше галасу

Голодної юрби» [11]

Про мешканців міста герой публікації говорить:

«Ваша блідна нікчемність

Волає до смороду брудної Лопані...

Замість життя радісного немовлятки,

Абортована думка ваша,

Зійде гнилою кров'ю» [11]

Така люта характеристика невдовзі змінюється в героя нарису на поглинання і перетворення його на зовсім іншу людину, яка стає врешті у місті своїм. На підставі цієї публікації можна прослідкувати тенденції співіснування і розвитку української селянської та міської культури, певне їхнє протистояння.

Цікаву інформацію про громадсько-політичні настрої, світогляд частини української еміграції знаходимо на сторінках збірника «Державна Нація»- неперіодичного органу Легії Українських Націоналістів, що у двох примірниках вийшов у Празі у 1927 р. Метою авторів збірника був розрив 3 українофільською традицією і виховання молоді на цілковито інших засадах, ніж це вважалося до того часу в українському патріотичному середовищі. Серед авторів збірника $є$ такі відомі особистості українського культурно-політичного руху, як Д. Донцов, М. Сціборський, Є. Маланюк, Ю. Липа. [12] На сторінках видання автори розмірковували щодо причин поразок українського національно-визвольного руху у 1917 - на початку 1920-х років. Серед причин невдач, на думку одного з авторів, - нерозуміння психології селянських мас, що призводило до краху всіх заходів у справі виконання селянством обов'язків щодо держави. Керманичів визвольним рухом картали за м'якотілість, що призводило до поразок. Критикувалися загальносвітові концепції розвитку: «Життя не хоче знати інтернаціональних мрій, принципів, - воно нищить їх». Завданням виховання молодого покоління $є$ плекання іii рішучості, тверезо дивитися на сьогодення, пристосовувати свою діяльність до вимог часу. Молодь має спиратися на власні ідеї, а не пристосовуватися до чужих чи толерувати ворога. Родина посідає важливе місце у розвитку народу, вона є основою організованої нації. [13] М. Сціборський у збірнику відверто негативно характеризує тогочасний стан української еміграції: «Еміграція гниє, вірніше догниває... Одна частина іiі, зневірена щодо наслідків та рації дальшої боротьби, вільно чи невільно ренегатствує й зміновіхає. Друга уявляє з себе інертну масу, яка живе лише своїми егоїстичними інтересами й шуканням шматка хліба. Третя, розпорошена на безліч різних партій, груп і «центрів», відбуває марну вакханалію взаємних поборень. Ми не помилимося, коли ствердимо, що тепер еміграція далеко не уявляє з себе організованого, активного, 
будуючого політично-національного чинника» [14]. На сторінках видання подається аналіз особливостей політичних суперечностей у емігрантському середовищі, що тлумачиться не політичними причинами, а світоглядними принципами, які не сприяють консолідації нації [15]. Характеризуючи соціальні відносини в Україні під більшовицькою владою, автори збірника пишуть про зростання злиднів та антисанітарних умов, а народна освіта і виховання під гаслом матеріалістичного світогляду отруїли душу цілої генерації. [16] Середовище, чиї погляди висвітлювалися і викристалізовувалися на шпальтах «Державної Нації», було одними з фундаторів створення у 1929 р. ОУН.

Одним із найвідоміших часописів міжвоєнного періоду була «Нова Україна», що почала виходити у Празі з 1922 р. Редакцією видання позиціонувалося позапартійним двотижневиком. Для нас науковий інтерес становить той факт, що публікації «Нової України», крім економічних, політичних питань велику увагу приділяють культурнопросвітницькому, громадському розвитку. Серед завдань цього видання був об’єктивний аналіз становища в Україні, пошук шляхів відбудови рідного краю. Навколо часопису згуртувалися відомі українські літературні, наукові, публіцистичні діячі [17].

У виданні відслідковується ситуація у різних частинах України. Так, за 1922 р. повідомлялося про голод серед мільйонів, поширення епідемій тифу, холери. [18] У публікаціях 1923 р. - про голод на Запоріжжі, Миколаївщині. [19] Повідомляючи про голод у приморських місцевостях України, часопис висловлює думку про те, що Москва таким чином знищує українців, здійснюючи колонізаційні плани: на виморених голодом територіях поселити нових поселенців. [20]

Цікавою $є$ рубрика видання «На Україні», автором якого підписаний «Киянин». Рубрика містить багато цінної інформації щодо різних аспектів життя українців під більшовицькою владою. Значна частина цієї інформації присвячена повсякденному життю селянства, його ставленню до міста. У 1923 р. часопис писав про те, що більшовицька влада тепер шукає 3 селом «змичку», намагається призначити 3 числа лояльних до влади представників різних структур «шефів» над селом. Селянство реагує на такі заходи і на візити представників влади як на чергову спробу вилучити якнайбільше податків, бо не вірить, що комуністи організовують такі заходи для добра українського села. На підставі аналізу більшовицької преси, видання «Нова Україна» пише про те, що комуністична влада усвідомлює підозріле ставлення й боязкість селян щодо експедицій представників держави до села та різного над ним «шефства». Все місто в цілому розглядається як осередок ворожої влади, чужих урядовців, незрозумілих законів. На думку селянства, місто тільки й може, що вимагати податки, а за невиконання - карає, воно ворог, для звичайного селянина від нього слід сподіватися одного лиха. Культурні надбання (давні й нові) міста для українського села - незрозуміла, неприступна, чужа річ, що суперечить побутові села. Для селянина міста уособлюються як осередки різного людського непотребу: нероб, дармоїдів, гультяїв, що лише те й роблять, як вештаються та бенкетують. Ці бенкети й неробство містян, на думку селянина, забезпечує праця села. Події, пов'язані 3 «воєнним комунізмом», що супроводжувалися реквізиціями, націоналізацією, господарською руїною, стимулювали зміцнення селянських стереотипів щодо міста [21]. Далі у публікації подається опис того, як у 1921 р. представники влади приїхали до одного українського села, організували там мітинг, допоки селяни попросили сказати нарешті: «Тепер весна, робити треба, а ми стоїмо. Скажіть прямо: скільки вам пудів треба?..»[21] Проблема «змички» села та міста розглядається в наступних публікація рубрики. Часом про це явище пишеться 3 іронією: «А щодо «смычки» компартії, «внєшторга» та «хлібопродукта» 3 селянською стихією, то це робиться так: беруть авто, відповідну кількість омарів, членів комуністичної партії, стільки ж совітських «баришень» і гайда «смикатися» 3 селом! Просто й невибагливо!» [22]. Під час таких виїздів до села представників більшовицької влади, українські селяни бачать $з$ боку начальства гультяйство, навантажені делікатесами та алкоголем автомобілі, зловживання коштами від державних податків. Обурення та недовіру до міських «шефів» викликало у селян запрошення 66 представників незаможників до Полтави, де вони взяли участь у подібних бенкетах: «недовір'я до чистоти пролетарського існування міських товаришів зросло після цього». [22] Селяни налаштовані до мешканців міста негативно, бо «робітники живуть добре, й цигарки палять, і до театру вчащають, чоботи носять. Тому ціни високі. Всі тягарі спадають на селянство. А нам тичуть під ніс «смичку» 3 містом. Коло влади - робітники. Тому воно так і виходить», - так висловлювалися селяни на Поділлі у 1924 р. [20]

Цікаві матеріали про повсякдення і побут селянства в середині 1920-х років в Україні розміщені на сторінках видання. На прикладі села Глибне Верхньосироватської волості Харківської округи описується умови життя тогочасного селянства. Замість вбраної колись у рушники хати - голі, закурені стіни та стеля, майже цілковитий брак внутрішнього облаштування. Напівзруйновані меблі (стіл, стільці, дощатий тапчан, що слугує ліжком), декілька глечиків та мисок, почорнілі ікони. Зовнішній вигляд селян незадовільний - змарнілі, у зношеному полотняному одязі домашнього виробництва. Подібною була ситуація з побутовими умовами селянства Київини. Селяни майже не їдяь м'яса та сала, споживають здебільшого рослинні жири, в тому числі й малопридатні для харчування. Поширені випадки туберкульозу, що підтверджують місцеві лікарі. Від цієї хвороби страждають і люди, і худоба. Цілком занехаяна селянська взаємодопомога, а офіційні «Селянські комітети взаємодопомоги» не можуть розвивати ефективну діяльність в умовах окупаційного режиму. Селянству допікають різні бюрократичні перепони, надзвичайний контроль з боку влади, великі податки. Коли мова йде про чиновників в Україні, то визнається, що це майже завжди неосвічені особи. [1-3 1924, с. 202-206] За визнанням бі- 
льшовицької влади, суспільний рівень селянства значно вище рівня сільських комуністів, котрі ані досвіду, ані тями не мають і на критику здатні відповідати лише заяложеними компартійними фразами. [1 1925, с. 89]

У великих містах, за даними «Нової України» багато безпритульних дітей, про яких влада воліє не говорити. Зокрема, безхатьків приваблюють залізниці, вони тиняються по лінії, вагонах, потягах. [1-3 1924, c. 206]

На сторінках «Нової України» мова йде про становище вчителів в українському селі. Для того, щоб заробити на життя, сільські вчителі змушені працювати наймитами в орендарів чи заможніших селян. До сфери їхньої вимушеної господарської діяльності входили й праця на землі, виготовлення рушників та сорочок для чужих весіль. Кваліфіковане вчительство, як зауважує рубрика «На Україні», на підставі вивчення даних 3 комуністичної періодики, пішло шукати собі роботу. «Велика більшість учительства, особливо на селі, не на своєму місці, бо неуки... Або село зостанеться без учителя, або «вчителі» будуть калічити наше молоде покоління... - що хочете, те й вибирайте». [ч10, с. 135]

Проблема розвитку школи і освіти на українських землях піднімалася на шпальтах «Нової України» неодноразово. На Волині у 1922 р. вчителі продовжували голодувати. Це відбувалося на тлі затримок заробітної плати, що становили від 4 до 6 місяців. Навіть після виплати неповної заробітної плати, влада вдавалася до різних «добровільних» позик. Видання пише, що вчителі змушені ходити голодні, у страшному лахмітті, без чобіт. Десятки шкіл порожні через брак учителів. Педагоги втікають зі шкіл і воліють працювати сторожами, двірниками, міліціонерами, бо праця цих категорій оплачується незрівнянно краще. «Один дуже популярний у Житомирі педагог, по скінченню навчання в школі, йде на роботу сажотрусом, і тим заробляє більше, ніж лекціями. Але школи все-таки не кидає». [16-18 1922, с. 72] Видання пише: українські селяни відверто вороже ставляться до вчителів-комуністів. Наприклад, на Волині їх просто виганяють, що зробити неважко, оскільки уряд фактично не забезпечує утримання вчителів. Рятуючись від голоду, вони мусять тікати. [16-18, 1922, с. 75]

На Запоріжжі станом на 1923 р. ситуація з умовами життя вчительства була вкрай складною. Зокрема, в Оріхівському районі, що постраждав від голоду. Шкільні робітники повністю незабезпечені, погано харчуються, змушені продавати останні речі. Місцеве ж населення фізично не в змозі прогодувати вчителів. [4, 1923, с. 128]

Практично недосяжною $є$ купівля книжок для навчання, 80\% учнів їх не має. До школи потрапляє лише $30-50 \%$ учнів. [1-3 1924, с. 207]

У рубриці «Освітні й учительські справи» подано матеріал про становище в Київському університеті. На 1923 р. там навчалося 2500 осіб (44\% українці, 39\% - євреї, 17\% - росіяни), 54\% 3 них жінки. У часописі повідомлялося, що за несплату навчання на початок березня 1923 р. було відраховано 600 осіб. Члени комуністичної партії користу- валися пільговим правом навчатися безкоштовно, інші категорії мусили платити за навчання від 20 до 40 карбованців золотом. Влада намагалася згуртувати так зване «пролетарське студентство» у професійні осередки з метою залучити їх до «радянського будівництва». Для того, щоб не вмерти з голоду та мати змогу заплатити за навчання, студенти мусили працювати. Стабільну роботу їм було знайти важко, через це вони влаштовувалися прибиральниками вулиць, сторожами. Вказана інформація виданням наведена 3 посиланням на приватний лист, одержаний одним із членів Громадського Комітету Австрії. [19, с. 127]

У 1922 р. видання вказувало на вражаючий рівень неписьменності на Закарпатті: «Підкарпатська Русь, це країна анальфабетів. I досі там нараховується 80\% неграмотних». [23, с. 29] Причини такої ситуації вбачалися у цілеспрямованій політиці панівної угорської влади. Крім цього, закарпатські селяни під впливом агітації шинкарів, боялися віддавати дітей до школи, щоб там не відвернули в них віру у Бога, бо, мовляв, усі вчені не релігійні. Аналізуючи проблеми шкільництва, автор публікації вказує й на те, що негативно на розвиток освіти вплинула діяльність священиків, які не хотіли розповсюдження світських навчальних закладів, а наполягали лише на розбудові релігійних. Негативно на рівень освіти вплинув також той фактор, що на посади вчителів на Закарпатті чеським урядом призначалися росіяни, які не розуміли народної мови, а воліли поширення «язичія», якого не сприймав сам народ. Коли почали призначати до нижчих та середніх шкіл учителів, які володіли народною мовою, фахівців, серед яких був високий рівень українців, то відвідуваність шкіл стає удвічі-тричі вищою.

У публікації наголошувалося на важливості навчання дітей рідною мовою. Вказувалося, що протягом трьох останніх років на Підкарпатській Русі постало 700 народних шкіл, серед яких 550 українських, 10 міських (8 українських), 3 реальних гімназії, 3 вчительські семінарії, 2 торгівельні академії, 9 промислових шкіл. Серед недоліків середньої шкільної освіти на Закарпатті вказувався брак справних шкільних будинків, відсутність належної кількості вчителів, санітарно-гігієнічного догляду. Для того, щоб діти з гірських районів могли навчатися, урядом у великих містах і селах створювалася мережа інтернатів, де за відносно невисоку платню, діти мали тепле й чисте помешкання, гарних педагогів. Зокрема, такі заклади існували у Береговому, Ясіню. У зазначеній публікації автор наголосив на ролі товариства «Просвіта» у поширенні освіти. Позитивно впливали на просвітництво діяльність спеціальних мандрівних театральних труп, що не лише ставили п'єси, але й показували кіно [23, с. 30-31].

«Нова Україна» подавала цікаву інформацію про функціонування в Подєбрадах Української господарської академії. Висвітлювалися наукові здобутки та публікації викладачів. Було докладно описано різні навчальні кабінети, кафедри. Описувалися побутові умови праці та навчання в цьому закладі, зокрема студентська їдальня, де за помірну ціну можна харчуватися значно краще, ніж, навіть, у 
деяких освітніх закладах Праги. Автор публікації пише про це, як про заслугу діяльності студентського кооперативу та самоврядування. Бібліотечний фонд освітньої установи поповнювався за рахунок засобів емігрантського бюджету, безкоштовних видань, надісланих чеськими урядовими установами, жертводавцями [18, с. 77-80].

На сторінках видання $є$ публікації, присвячені й іншим навчальним закладам Чехословаччини. Зокрема, Українському Інституту Громадознавства, Українському Робітничому Університету у Празі. Висвітлюються загальні тенденції наукового, повсякденного життя у цих закладах [24, с. 72-73].

Окрему увагу «Нова Україна» приділила висвітленню студентського життя у Східній Галичині, Волині, Холмщині, Підляшші, Буковині, Чехословаччині, в країнах Західної Свропи. [18, с. 80]

Однією 3 найгірших, на думку часопису, була українська шкільна справа на Буковині. Станом на 1922 р. тут було закрито 9 народних шкіл, що позбавило 17000 українських дітей змоги навчатися. На місце закритих українських шкіл впроваджувалися румунські, а в незакритих українських школах примусово навчали румунською мовою історії, географії. Українську історію вивчати заборонялося. Усе це відбувалося на тлі переслідування українських вчителів з боку влади. Як проблему було визначено засилля вчителів-румунів, котрі не знали місцевої мови, нав'язували румунський патріотизм. Усі українські середні школи закрито, залишилася лише одна чернівецька гімназія, яку було румунізовано. Автор публікації описує випадок, коли учнівукраїнців чотирьох старших класів чернівецької гімназії було ув'язнено за нібито знищення дерев, посаджених на згадку про коронацію румунського короля. Громадські об’єднання української молоді переслідувалися владою. Ситуація склалася настільки гостро для українських учнів, що, навіть за читання українських літературних творів могли виключити зі школи.

Катастрофічною для українців під владою Румунії була ситуація у сфері вищої освіти. Досвідчених професорів замінено румунами, які до того часу працювали в галузі середньої освіти. Мова викладання - румунська, хоча, як вказує автор, 80\% студентства тієї мови не знало. Кафедра української мови була закрита у 1920 р., бажання студентства мати кафедру української історії залишалося нездійсненною мрією. Автор підсумовував статтю такими словами: «У такому морі ворожої ненависті, злоби й поневолення живе українська людність...». [25, с. 63-64]

На сторінках видання «Нова Україна» розміщувалися й твори художньої літератури: оповідання, п'єси, вірші. Представлені тут праці з історії української культури та мистецтва, [26], військової справи [27], становища українських робітників у еміграції [24, с. 82]. В одному 3 номерів «Нової України» розповідалося про свято Т. Шевченка у Подєбрадах у березні 1928 р. [28, с. 63-64]. Таким чином, можемо переконатися, що часопис «Нова Україна» значну увагу приділяв висвітленню проблем розвитку української культури, освіти, повсякденню українців на етнічних землях та в еміграції.

На сторінках тижневика «Тризуб», що виходив у 1925-1940 pp. у Парижі, у середовищі української еміграції публікувалися матеріали, що їх можна розглядати як джерела 3 дослідження соціокультурних процесів, повсякденного життя в Україні в умовах більшовицького панування. Тематика публікацій стосувалася різноманітних сфер життя української спільноти в УСРР: розвитку культури, внутрішнього світу людини, сприйняття дійсності, тлумачення змін у природі крізь призму суспільних перетворень, відносини мешканців міста і села, становище різних прошарків суспільства. [29; 30; 31]

Значна частина публікацій у «Тризубі» присвячена подіям українського громадського, культурного життя в еміграції. Наприклад, висвітлюється робота Міжорганізаційного Комітету для Вшанування i Оборони пам'яті С. В. Петлюри у Празі [32, с. 3031], громадські, культурні заходи української еміграції у Франції, Польщі, Чехії, країнах Америки [33, с. 22-25; 34, с. 19-27]. 3 публікацій цього видання можна довідатися про існування Українського Товариства прихильників книги (Прага). Завданням цієї громадської організації були такі напрямки роботи: видання періодичних та інших друкованих праць, проведення наукових дискусій у межах Товариства, організація нарад та з’їздів у книжковій справі, поширення літератури, організація книжкових виставок, бібліотек, бібліографічних збірників, проведення лекцій та курсів з галузі українського книгознавства, участь у роботі аналогічних науковокультурних об'єднань, організація конкурсів, призначення премій. Головою організації обрано професора С. Сірополка, а на інші провідні посади у Товаристві - інших авторитетних у культурнопросвітницькій галузі діячів української еміграції. Організація протягом короткого часу встигла провести ряд засідань, на яких розглядалися актуальні проблеми української культури. [34, с. 23-24]. У іншому номері часопису мова йшла про функціонування української бібліотеки в Омекурі (Франція). [35, с. 30] На сторінках видання також подавалася інформація про діяльність українських наукових закладів на еміграції. Одна з публікацій присвячена діяльності Українського Наукового Інституту в Берліні. Ініціатором створення цього закладу було гетьманське середовище в Німеччині. Діяльність Інституту полягала в науковій роботі, для чого було засновано кафедру історії України з підвідділами історії української державності та історії внутрішнього життя українського народу; кафедр, де мали вивчатися різні духовні течії в Україні, пов'язані $з$ духовним життям інших слов'янських народів; кафедру українського мистецтва та матеріальної культури; народного господарства України; історії українського права, мови, письменства, етнографії. [35, c. 12-15]

На шпальтах інших періодичних видань української еміграції не містяться матеріали з висвітленням соціокультурних проблем та повсякденного життя емігрантів. Проблеми інтернованих українських вояків висвітлюються в таких часописах: «Голос 
табора» (Німецьке Яблонне, 1919-1920), «Український скиталець» (Ліберець, 1920-1921), «Український стрілець» (Ліберець-Йозефів, 1920). Цікаві матеріали можна знайти у виданнях «Воля» (Відень, 1920), «Табір» (Каліш, Варшава, 1923-1928). Окреме місце посідають видання української емігрантської молоді. Зокрема, слід назвати часопис Української Господарської Академії в Подєбрадах - «Подєбрадка» (1924). Серед кількох сотень українських видань у Чехословаччині можна назвати такі, як «Розбудова Нації» (19281934), «Наша спілка» (1923-1926). У Німеччині виходили часописи «Український прапор» (1922-1932), «Українське слово» (1921-1926). У Польщі у 1920-ті роки українці видавали «Духовний сіяч» (1927-1931), «Український інвалід» (19231931), в Австрії - «Український прапор» (19191920), «Боротьба» (1920), «Молоде життя» (1921), «Борітеся - поборете!» (1920-1922), «Український філателіст» (1925-1939), «Соборна Україна» (19211922). [37] У цих та інших виданнях автори публікацій піднімали нагальні проблеми життя українського народу на українській етнічній території та в еміграції.

ВИСНОВКИ. Отже, в українській емігрантській пресі 1920-х років широко представлені питання, що стосувалися актуальних проблем становлення та розвитку української культури (література, мистецтво, театр). У деяких виданнях значну увагу приділено стану української освіти як на українських землях під владою більшовиків, так і на українських теренах у складі Польщі, Румунії, Чехословаччини, у країнах Західної Свропи, Америці. Ряд видань робило спробу висвітлювати та аналізувати повсякденне життя українців. Описувався побут українського селянства під більшовицькою владою, ставлення українського села до міста, до чиновників і влади взагалі. На шпальтах емігрантських видань висвітлені складні відносини в українському середовищі. Таким чином, можна констатувати, що українська емігрантська преса може слугувати джерелом вивчення культури, освіти, повсякденного життя українців.

\section{ЛІТЕРАТУРА}

1. Животко А. Історія української преси. Мюнхен: Ukrainisches Technisch-Wirtschaftlichen Institut, 1989-90. 334 c.

2. Мартинюк М. Українські періодичні видання Західної України, країн Центральної та Західної Свропи (1914-1939 рр.) Львів: ЛНБ ім. В. Стефаника, 1998. 298 с.

3. Лисяк-Рудницький I. Між історією і політикою. Статті до історії та критики української суспільно-політичної думки. Мюнхен: Сучасність, 1973. $441 \mathrm{c}$.

4. Сидоренко Н. «Задротяне життя» українських часописів на чужині (1919-1924). Київ: дослідницький центр історії української преси, 2000. 88 с.

5. Вішка О. Преса української еміграції в Польщі (1920-1939 рр.): Історико-бібліографічне дослідження. Львів: Вид-во Львівської обласної друкарні, 2002. $480 \mathrm{c}$.

6. Савка М. Українська еміграційна преса у Чехословацькій Республіці (20-30-ті рр. ХХ ст.): Істо- рико-бібліографічне дослідження. Львів: НАН України. Львівська наукова бібліотека ім. В.Стефаника, 2002. 308 c.

7. Денека О. Українська еміграційна преса у Франції 20-30-х рр. ХХ ст.: становлення, розвиток, проблематика. Київ, 2003. 180 с.

8. Трощинський В. Міжвоєнна українська еміграція в Свропі як історичне і соціально-політичне явище. Київ: Інтел, 1994. 260 с.

9. Богуславський О. Преса міжвоєнної української еміграції і боротьба за незалежність України: історичний шлях, досвід, дискусії. Монографія. Запоріжжя: Просвіта, 2008. 452 с.

10. Крупський I. Преса як джерело досліджень національно-визвольних змагань за Українську державу (Друга половина XIX - перша чверть XX ст.): Автореф. дис. ... д-ра іст. наук / НАН України, Ін-т укр. археографії та джерелознавства ім. М. С. Грушевського. Київ, 1996. 30 с.

11. Дніпровський А. Індустріяльні мотиви в селянській поезії. Нова Громада. Суспільнополітичний журнал. 1923. № III-IV C. 79-83.

12. Державна нація. Неперіодичний збірник. Кн.1. Прага, 1927. 48 с.

13. Нововірський Н. До переоцінки вартостей // Державна нація. Неперіодичний збірник. Кн.2. Прага, 1927. С. 3-6.

14. Сціборський М. Шлях Націоналізму // Державна нація. Неперіодичний збірник. Кн.2. Прага, 1927. С. 6-13.

15. Огляд журналів // Державна нація. Неперіодичний збірник. Кн.2. Прага, 1927. С. 31-35.

16. Покерт В. Два жовтня // Державна нація. Неперіодичний збірник. Кн.2. Прага, 1927. С. 23.

17. Брайлян Н. Журнал «Нова Україна» (Прага, 1922-1929 рр.) як джерело до бібліографії української періодики // Збірник праць Науководослідного інституту пресознавства. 2013. Вип. 3. С. 233-243.

18. Нова Україна. 1922. № 16-18.

19. Нова Україна. 1923. № 4.

20. Киянин. На Україні // Нова Україна. 1925. № 1. С. 82-93.

21. Киянин. На Україні // Нова Україна. 1923. № 7-8. С. 254-265.

22. Киянин. На Україні // Нова Україна. 1923. № 9. С. 119-129.

23. Гончаренко А. На Підкарпатській Україні // Нова Україна. 1922. № 16-18. С. 28-37.

24. Нова Україна. 1927. № 12.

25. Вигнаний В. На зеленій Буковині // Нова Україна. 1922. № 16-18. С. 61-64.

26. Антонович Д. Українське мистецтво // Нова Україна. 1923. № 3. С. 107-115.

27. Петрів В. Суспільство й військо. Соціяльноісторичний нарис // Нова Україна. 1924. № 1-3. C. $109-142$.

28. Нова Україна. 1928. № 1-3.

29. Степовик. Лист з України // Тризуб. 1926. № 17. C. 10 .

30. Степовик. Лист з України // Тризуб. 1926. № 22. C. 12-16.

31. Вітер з України // Тризуб. 1926. № 48. С. 10. 
32. Тризуб. 1926. № 55.

33. Тризуб. 1926. № 58.

34. Тризуб. 1927. № 10(68).

35. Тризуб. 1927. № 12(70).

36. Тризуб. 1927. № 7(65).
37. Мушинка М. Виставка української емігрантської преси в Празі // Український журнал. Прага, 2009. № 6. С. 10-11.

\section{THE PRESS OF UKRAINIAN EMIGRATION AS SOURCE OF STUDY OF CULTURE, EDUCATION AND EVERYDAY LIFE OF UKRAINIANS (1920th YEARS)}

\section{O. Vovk}

Sumy State A. S. Makarenko Pedagogical University

vul. Romenska, 87, Sumy, 40002, Ukraine. E-mail: o.v.vovk@ gmail.com

Purpose. The aim of the article was to analyse the press of Ukrainian emigration as source of study of culture, education and everyday life of Ukrainians in 1920th. Methodology. We are use the scientific methods of analysis and synthesis, chronologic, logical, synchronous, methods of research of historical sources (fixing time and place of historical source, finding out of circumstances of origin of historical source, verification of maintenance of historical source). Results. There is a row of sources that give an opportunity to learn the question of sociocultural development, Among the mentioned sources that illustrate life of Ukrainians in 1920th, it is separately possible to distinguish the press. The magazines of the Ukrainian diaspore have it is certain ideological position. Comparing to the newspapers and magazines of Ukraine that was under bolshevist occupation, the press of Ukrainian emigration had considerably anymore possibilities objectively to light up the problems of development of education, culture on Ukrainian earth and emigration. At the USSR objective illumination of public processes was impossible, taking into account the totalitarian mode. To check objectivity of information in the magazines of Ukrainian emigration we can by the study of the archived documents, analysis of remembrances of eyewitnesses of historical events. The scientific publications sanctified to this historical period certify that on the whole materials of the foreign press mostly objectively light up directions of development of culture, education, everyday life of Ukrainians that lived under bolshevist occupation. The foreign press is for us a valuable enough source in the context of study of cultural process in the environment of the Ukrainians nebulized among different countries. In the Ukrainian emigrant press of 1920th the widely presented questions that touched the issues of the day of becoming and development of the Ukrainian culture (literature, art, theatre). In some magazines considerable attention is spared to position of Ukrainian education both on Ukrainian earth under power of bolshevists and on Ukrainian territories in composition Poland, Romania, Czechoslovakia, in the countries of Western Europe, America. Row of magazines gave it a shoot to light up and analyse everyday life of Ukrainians. The way of life of the Ukrainian peasantry was illuminated under bolshevist power, attitude of the Ukrainian village toward a city, to the officials, power. On the pages of emigrant magazines difficult relations are lighted up in the Ukrainian environment. The Ukrainian emigrant press can serve as the source of study of culture, education, everyday life of Ukrainians. Originality. The press of Ukrainian emigration as historical source of everyday life of Ukrainians is analysed on the ethnic territory and in emigration. Practical value. Research results can serve for preparation of lecture, scientific programs from history of the Ukrainian culture, history of the Ukrainian press, history of Ukrainian emigration.

Key words: the press, culture, education, source, everyday life

\section{REFERENCES}

1. Zhyvotko, A. (1989-90), Istoriia ukrainskoi presy [History of Ukrainian press], Munich, Germany.

2. Martyniuk, M. (1998), Ukrainski periodychni vydannia Zakhidnoi Ukrainy, krain Tsentralnoi ta Zakhidnoi Yevropy (1914-1939 rr.) [Ukrainian magazines of Western Ukraine, countries of Central and Western Europe (1914-1939)], Lviv, Ukraine.

3. Lysiak-Rudnytskyi, I. (1973), Mizh istoriieiu ta politykoiu. Statti do istorii ta krytyky ukrainskoi susplno-politychnoi dumky [Between history and politics. The articles are to history and criticism of the Ukrainian social and political idea], Munich, Germany.

4. Sydorenko, N. (2000), "Zadrotiane zhyttia" ukrainskykh chasopysiv nz chuzhyni (1919-1924) ["Life after a prickly wire" of the Ukrainian magazines on strange land (1919-1924)], Kyiv, Ukraine

5. Vishka, O. (2002), Presa ukrainskoi emihratsii v Polshchi (1920-1939 rr.): Istoryko-bibliohrafichne doslidzhennia [The press of Ukrainian emigration is in Poland (1920-1939): Historian-bibliography research], Lviv, Ukraine.

6. Savka, M. (2002), Ukrainska emihratsiyna presa u Chekhoslovachchyni (20-30-ti rr. XX st.): Istoryko- bibliohrafichne doslidzhennia [The Ukrainian emigrant press is in Czechoslovak Republic (20-30th XX of century): Historian-bibliography research], Lviv, Ukraine.

7. Deneka, O. (2003), Ukrainska emihratsiyna presa u Frantsii 20-30-kh XX st.: stanovlennia, rozvytok, problematyka [The Ukrainian emigrant press in France 20-30th of XX of century : becoming, development, range of problems], Kyiv, Ukraine.

8. Troshchynskyi, V. (1994), Mizhvoienna ukrainska emihratsiia $v$ Yevropi yak istorychne $i$ sotsialnopolitychne yavyshche [Ukrainian emigration in Europe as the historical and socio-political phenomenon between two world wars], Kyiv, Ukraine.

9. Bohuslavskyi, O. (2008), Presa mizhvoiennoi ukrainskoi emihratsii i borotba za nezalezhnist Ukrainy: istorychnyi shliakh, dosvid, dyskusii. Monohrafiia. [The press of intermilitary Ukrainian emigration and fight for independence of Ukraine : historical way, experience, discussions. Monograph], Zaporizhzhia, Ukraine.

10. Krupskyi, I. (1996), Presa yak dzherelo doslidzhen natsionalno-vyzvolnykh zmahan za Ukrainsku derzhavu (Druha polovyna XIX - persha chvert XX st.): Avtoref. dys. ... d-ra ist. Nauk [The press 
as source of researches of national liberation competitions is for the Ukrainian state (The second half of XIX is the first fourth of XX of century)], Kyiv, Ukraine.

11. Dniprovskyi, A. (1923), "Industrial reasons are in a peasant poetry", Nova Hromada, № III-IV, pp. 7983.

12. Without author (1927), Derzhavna natsiia. Neperiodychnyi zbirnyk. B. 1, Prague, Czechoslovakia.

13. Novovirskyi, N. (1927), "To the overvalue of values", Derzhavna natsiia. Neperiodychnyi zbirnyk, B. 2, pp. 3-6, Prague, Czechoslovakia.

14. Stsiborskyi, M. (1927), "The Way of Nationalism", Derzhavna natsiia. Neperiodychnyi zbirnyk, B. 2, pp. 6-13, Prague, Czechoslovakia.

15. Without author (1927), "The Review of Journals", Derzhavna natsiia. Neperiodychnyi zbirnyk, B. 2, pp.31-35, Prague, Czechoslovakia.

16. Pokert, V. (1927), "The Two Lives", Derzhavna natsiia. Neperiodychnyi zbirnyk, B. 2, p. 23, Prague, Czechoslovakia.

17. Brailian, N. (2013), "A magazine "Nova Ukraina" (Prague, 1922-1929) as source is to bibliography of the Ukrainian periodicals", Zbirnyk prats Naukovo-doslidnoho instytutu presoznavstva, № 3, pp. 233-234.

18. (1922), Nova Ukraina, № 16-18.

19. (1923), Nova Ukraina, № 4.

20. Kyianyn (1925), “In Ukraine”, Nova Ukraina, № 1, pp. 82-93.
21. Kyianyn (1923), “In Ukraine”, Nova Ukraina, № 7-8, pp. 254-256.

22. Kyianyn (1923), "In Ukraine”, Nova Ukraina, № 9, pp. 119-129.

23. Honcharenko A. (1922), "In Pidkarpattia Ukraine”, Nova Ukraina, № 16-18, pp. 28-37.

24. (1927), Nova Ukraina, № 12.

25. Vyhnanyi, V. (1922), "On Green Bukovyna", Nova Ukraina, № 16-18, pp. 61-64.

26. Antonovych, D. (1923), "Ukrainian art", Nova Ukraina, № 3, pp. 107-115.

27. Petriv, V. (1924), "Society and army. Socialhistorical essay”, Nova Ukraina, № 1-3, pp. 109142.

28. (1928), Nova Ukraina, № 1-3.

29. Stepovyk (1926), "Letter from Ukraine", Tryzub, № 17 , p. 10.

30. Stepovyk (1926), "Letter from Ukraine”, Tryzub, № 22, pp. 12-16.

31. Without author (1926), "Wind from Ukraine", Tryzub, № 48, pp. 10.

32. (1926), Tryzub, № 55.

33. (1926), Tryzub, № 58.

34. (1927), Tryzub, № 10(68).

35. (1927), Tryzub, № 12(70).

36. (1927), Tryzub, № 7(65).

37. Mushynka, M. (2009), "An exhibition of the Ukrainian emigrant press is in Prague", Ukrainskyi zhurnal, № 6, pp. 10-11, Prague, Czech Republic.

Стаття надійшла 23.05.2019. 